\title{
AKTIVITAS ANTIOKSIDAN FRAKSI N-BUTANOL TANAMAN LIBO (Ficus variegate Blume)
}

\author{
Olvira Esa Nurtiwi, Dewi Rahmawati, Rolan Rusli* \\ Laboratorium Penelitian dan Pengembangan FARMAKA TROPIS Fakultas Farmasi \\ Universitas Mulawarman, Samarinda, Kalimantan Timur \\ *email: rolan@farmasi.unmul.ac.id
}

\begin{abstract}
Antioxidants are molecules that can prevent or slow cell damage. Libo (Ficus variegate Blume ) is one of many wild plants species that has a potential source of antioxidant. However, the research on fractionated Libo has not been done. The aims of this study is to observe the antioxidant activity of Libo n-butanol fraction. The Libo dried leaves extracted with methanol, the methanol extract then fractionated with n-hexane, ethyl acetate and nbutanol to obtain n-butanol extract of Libo. Antioxidant activity was performed by DPPH radical scavenging method with 30 minutes of incubation time for each series of concentration from the $n$-butanol fraction with three replication The IC50 value of Libo $n$ butanol fraction obtained at 36,30 ppm.
\end{abstract}

Key words: Antioxidants, Libo, $\mathrm{IC}_{50}$

\begin{abstract}
ABSTRAK
Antioksidan adalah bahan yang membantu melindungi sel-sel tubuh dari efek buruk radikal bebas. Tanaman Libo (Ficus variegate Blume) merupakan salah satu jenis tanaman liar yang memiliki potensi sebagai salah satu bahan antioksidan. Namun, penelitian antioksidan tanaman Libo pada tingkatan fraksi belum banyak dilakukan. Penelitian ini bertujuan untuk melihat aktivitas antioksidan dari fraksi n-butanol. Daun tanaman Libo yang telah dikeringkan diekstraksi dengan pelarut metanol. Ekstrak metanol tanaman Libo yang dihasilkan, kemudian difraksinasi dengan pelarut n-heksan, kemudian etil asetat, dan diakhiri dengan n-butanol, sehingga didapatkan fraksi n-butanol. Fraksi kemudian dibuat variasi konsentrasidengan tiga replikasi dan direaksikan dengan larutan DPPH dengan waktu inkubasi selama 30 menit. IC $_{50}$ fraksi n-butanol tanaman Libo diperoleh sebesar $36,30 \mathrm{ppm}$.
\end{abstract}

Kata kunci: Antioksidan, Tanaman Libo, $\mathrm{IC}_{50}$

\section{PENDAHULUAN}

Radikal bebas adalah molekul yang tidak stabil dan sangat reaktif karena mengandung salah satu atau lebih elektron tidak berpasangan pada orbital luarnya. Secara normal tubuh dapat mengatasi efek radikal bebas, tetapi jika jumlah radikal bebas terlalu banyak, maka antioksidan endogen yang terdapat dalam tubuh tidak mencukupi sehingga radikal bebas tersebut dapat mengakibatkan kerusakan sel. Oleh karena itu, tubuh membutuhkan suatu substansi penting yaitu antioksidan yang mampu menangkal radikal bebas tersebut sehingga tidak menginduksi suatu penyakit (Hendyani,2015). 
Ada banyak jenis tanaman yang berpotensi sebagai bahan antioksidan. Salah satunya ada tanaman Libo (Ficus variegate Blume). Buah Libo telah dilaporkan memiliki banyak potensi, sebagai antioksidan, antibakteri, dan pestisida alami pada ekstrak metanol, fraksi etil asetat, $n$-hexan, $n$-butanol dan air (Rijai, 2013). Selain itu telah dilaporkan pula potensi daun tanaman ini sebagai antioksidan dan antibakteri pada fraksi $n$-hexan (Rusli, 2015).

Rijai (2013) melaporkan adanya potesi antioksidan kuat juga ditemukan pada fraksi n-butanol dari buah Libo. Penelitian ini dilakukan untuk mengukur aktivitas antioksidan fraksi n-butanol daun tanaman Libo terhadap peredaman DPPH (1,1-diphenil-2picrylhydrazyl). Diduga, selain buahnya, daun Libo juga memiliki potensi yang tidak jauh berbeda.

\section{METODE PENELITIAN}

Alat

Spektrofotometer UV-VIS (Double Beam Spechtrophotometer Dynamica), Seperangkat alat ekstraksi dengan metode maserasi, penyaring Buchner, Rotary vacuum evaporator, timbangan digital, seperangkat alat gelas, dan spatula.

\section{Bahan}

Simplisia daun tanaman Libo (Ficus variegate Blume), Metanol 96\%, Metanol p.a, Etil asetat, $n$-Hexan, dan $n$-Butanol, DPPH (Sigma Aldrich)

\section{Prosedur penelitian}

Sampel daun Libo (Ficus variegate Blume) dibuat menjadi simplisia dan diekstraksi dengan menggunakan metode maserasi dengan pelarut metanol. Kemudian, dipekatkan menggunakan rotary evaporator.

Ekstrak kental metanol daun Libo, difraksinasi menggunakan $n$-hexan, etil asetat kemudian n-butanol. Fraksi $n$-butanol daun Libo yang telah dikumpulkan, dibuat seri konsentrasi 10, 20, 40, 60, dan 80 ppm, direaksikan dengan larutan DPPH 40 ppm, dan diukur absorbansinya menggunakan spektrofotometer UV-Vis dengan panjang gelombang $515 \mathrm{~nm}$.

\section{HASIL DAN PEMBAHASAN}

Antioksidan disebut zat yang menghambat reaksi dari suatu zat dengan oksigen. Karena reaksi seperti ini lebih banyak melibatkan senyawa radikal, antioksidan lebih mengacu pada setiap zat yang menghambat reaksi radikal bebas (Baskin,1997).

DPPH merupakan radikal yang sangat stabil, telah digunakan untuk menentukan efek penghambatan radikal bebas dari beberapa antioksidan (Shahidi, 1997). Hasil dari uji aktivitas antioksidan fraksi n-butanol daun tanaman Libo dapat di lihat pada tabel 1.

Tanaman Libo dengan persen peredaman absorbansi DPPH, diperoleh persamaan regresi $\mathrm{y}=1,1034 \mathrm{x}+9,9585$. Berdasarkan hasil yang diperoleh (Gambar 1) dari persamaan regresi linier kemudian dapat menentukan harga $\mathrm{IC}_{50}$. Dari hasil perhitungan diperoleh harga $\mathrm{IC}_{50} 36,30 \mathrm{ppm}$.

Berdasarkan penelitian yang dilakukan oleh Febrina (2015), daun Libo memiliki kandungan senyawa fenol, flavonoid dan alkaloid. Senyawa-senyawa yang berpotensi sebagai antioksidan dapat diprediksi dari golongan fenolat, flavonoid dan alkaloid, yang merupakan senyawa-senyawa polar (Nurjanah, 2011). Diduga senyawa ini juga terdapat pada fraksi $n$-butanol daun Libo, karena n-butanol termasuk jenis pelarut polar. 
Tabel1. Hasil Pengujian Antioksidan Fraksi n-Butanol Daun Tanaman Libo (Ficus variegate Blume)

\begin{tabular}{ccccc}
\hline No. & Konsentrasi $(\mathrm{ppm})$ & Absorbansi & Rata-rata & \% inhibisi \\
\hline 1. & 10 & 0,634 & 0,63 & $14,979 \%$ \\
& 10 & 0,642 & & \\
2. & 10 & 0,614 & & $32,928 \%$ \\
& 20 & 0,507 & 0,497 & \\
3. & 20 & 0,491 & & $60,053 \%$ \\
& 40 & 0,494 & & \\
4. & 40 & 0,291 & 0,296 & \\
& 40 & 0,308 & & \\
& 60 & 0,279 & & \\
5. & 60 & 0,122 & 0,129 & \\
& 60 & 0,116 & & \\
& 80 & 0,149 & & \\
& 80 & 0,068 & 0,067 & \\
\end{tabular}

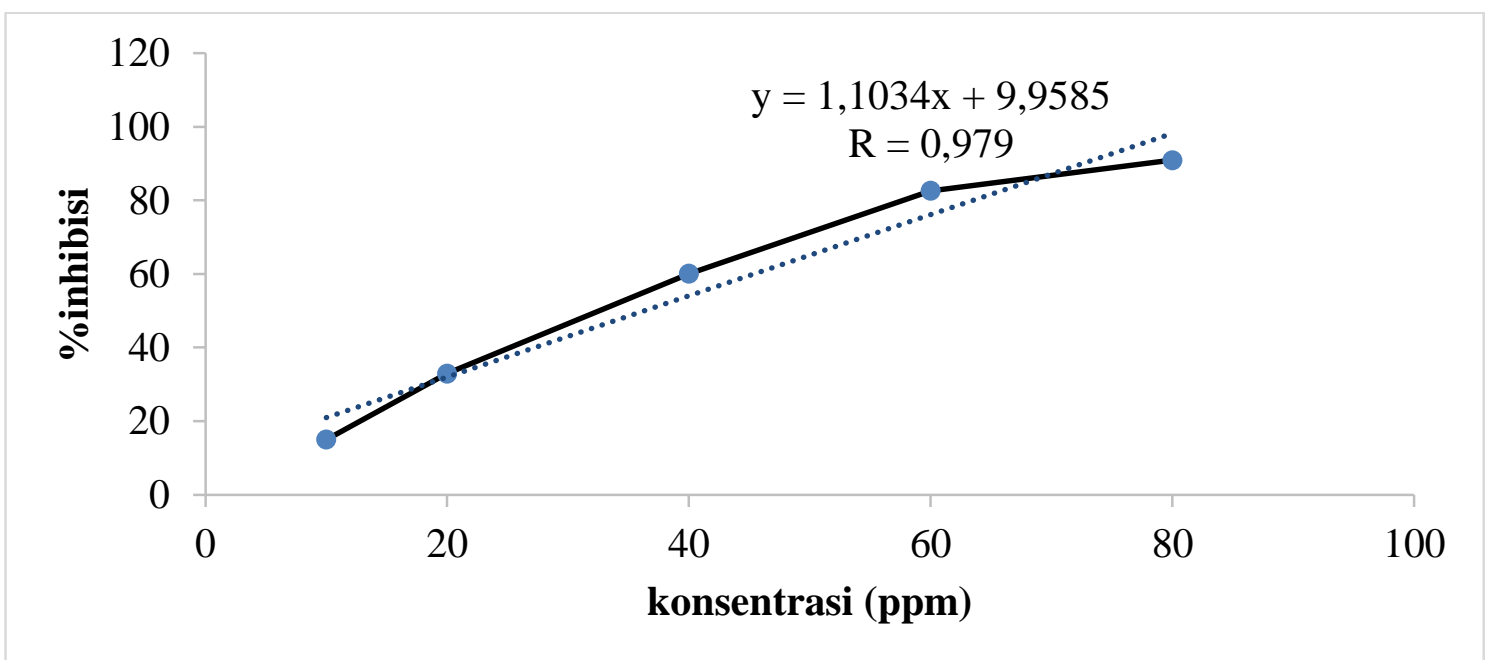

Gambar 1. Grafik Peredaman DPPH

Menurut Phongpaichit et al., 2007 suatu senyawa dinyatakan sebagai antiradikal bebas sangat kuat apabila nilai $\mathrm{IC}_{50}<10 \mu \mathrm{g} / \mathrm{mL}$, kuat apabila nilai $\mathrm{IC}_{50}$ antara $10-50 \mu \mathrm{g} / \mathrm{mL}$, sedang apabila nilai $\mathrm{IC}_{50}$ berkisar antara $50-100 \mu \mathrm{g} / \mathrm{mL}$, lemah apabila nilai $\mathrm{IC}_{50}$ berkisar antara 100-250 $\mu \mathrm{g} / \mathrm{mL}$ dan tidak aktif apabila $\mathrm{IC}_{50}$ diatas $250 \mu \mathrm{g} / \mathrm{mL}$. Hal ini nembuktikan bahwa fraksi n-butanol daun Libo memiliki efek antioksidan yang kuat.

Tinggi rendahnya aktivitas antioksidan dipengaruhi oleh berbagai faktor diantaranya adalah sifatnya yang mudah rusak bila terpapar oksigen, cahaya, suhu tinggi, dan pengeringan. 


\section{KESIMPULAN}

Berdasarkan penelitian yang telah dilakukan pada fraksi $n$-butanol daun tanaman Libo (Ficus variegate Blume) dapat disimpulkan bahwa, pada fraksi ini memiliki potensi sebagai antioksidan dengan kategori antioksidan kuat, yang ditunjukan dengan nilai $\mathrm{IC}_{50}$ sebesar 30,36 ppm.

\section{DAFTAR PUSTAKA}

1. Hendyani, Rosi., dkk. 2015. Ekstraksi Antioksidan Daun Sirih Merah Kering (Piper crotatum) dengan Metode Ultrasonic Assisted Extraction (Kajian Perbandingan Jenis Pelarut dan Lama Ekstraksi). Jurnal Bioproses Komuditas Tropis vol3 No.2

2. Rijai, Laode. 2013. Potensi Tumbuhan Libo (Ficus variegata Blume.) Sebagai Sumber Bahan Farmasi Potensial. Journal of Tropical Pharmacy and Chemistry, 2. (3). 166-179. DOI: https://doi.org/10.25026/jtpc.v2i3.63.

3. Rusli, R., Hardina, M.P., Muflihah, F., Rahmadani, A., 2015. Profil Kromatografi Senyawa Aktif Antioksidan dan Antibakteri Fraksi N-Heksana Daun Libo (Ficus variegata Blume.). Journal of Tropical Pharmacy and Chemistry, 3. (2). 124-130. DOI: https://doi.org/10.25026/jtpc.v3i2.98

4. Baskin, Steven I dan Harry Salem. 1997. Oxidants, Antioxidants, and Free Radicals. Taylor and Francis Publisher: United States of America.

5. Shahidi, Fereidoon. 1997. Natural Antioxidants. AOCS Press: Champaign, Illinois.

6. Febrina, Lizma, Rolan Rusli, Fairul Muflihah. 2015. Optimalisasi Ekstraksi dan Uji Metabolit Sekunder Tumbuhan Libo (Ficus Variegate Blume.). Journal of Tropical Pharmacy and Chemistry, 3. (2). 74-81. DOI: https://doi.org/10.25026/jtpc.v3i2.153

7. Nurjanah., dkk. 2011. Aktivitas Antioksidan dan Komponen Bioaktif Kerang Pisau (Solen spp). Jurnal Kelautan Vol. 16 (3).

8. Phongpaicit, S., et.al. 2007. Biological Activities of Extracts from Endophytic Fungi Isolated From Garciana Plants. FEMS Immunology and Medical Microbiology, 51 (3), 515-525. 